\title{
Microbial Profile and their Susceptibility Pattern in Ventilator Associated Pneumonia in a Tertiary Care Hospital
}

\author{
B. Shanthi, R. Selvi", V. Sheeba and P. Ponnammal \\ Stanley Medical College, Chennai - 600001, Tamil Nadu, India \\ *Corresponding author
}

\begin{tabular}{|l|}
\hline Ke y w o r d s \\
Ventilator Associated \\
$\begin{array}{l}\text { Pneumonia (VAP), } \\
\text { Intensive care unit, } \\
\text { Antibiotic resistance }\end{array}$ \\
\hline Article Info \\
\hline $\begin{array}{l}\text { Accepted: } \\
\text { 04 April } 2018 \\
\text { Available Online: } \\
\text { 10 May 2018 }\end{array}$ \\
\hline
\end{tabular}

\section{Introduction}

Ventilator Associated Pneumonia (VAP) is the most common intensive care unit (ICU) acquired nosocomial infection that develops when a patient is on mechanical ventilation for more than 48 hours and it is considered as the second most common hospital acquired infection associated with higher mortality and morbidity (Kalanuria et al., 2014; American Thoracic Society and Infectious Diseases Society of America, 2005).
Ventilator Associated Pneumonia (VAP) is the most common intensive care unit (ICU) acquired nosocomial infection and it is considered as the second most common hospital acquired infection associated with higher mortality and morbidity The aim of this study was to determine the microbial profile of pathogens causing VAP and their antibiotic susceptibility patterns over a period of five years in the intensive care unit (ICU) of a tertiary care hospital. Cross-sectional, descriptive study was done on patients who were on mechanical ventilation for more than 48 hours and clinically suspected of having pneumonia for the five consecutive years 2012 to 2016. During the study period significant growth of pathogens were found in 216 / 581patients. $90.27 \%$ were monomicrobial $9.72 \%$ ere polymicrobial. Pseudomonas aeruginosa was the most commonly isolated gram(3).49\%) followed by Klebsiella species 59 (28.64\%). An increase in resistance was shown by Pseudomonas aeruginosa and Acinetobacter spp. $58.49 \%$ of Klebsiella spp and $52.00 \%$ of Escherichia coli were ESBL producers. Staphylococcus aureus was the most commonly isolated gram positive bacteria (24), 18 $(75 \%)$ were Methicillin resistant (MRSA). Good management strategies for VAP like adequate infection control practices include hand washing by hospital personel, basic cleaning of all surface levels, increased barrier precautions, early accurate diagnosis and more specific antimicrobial use may significantly improve patients' outcome.
The estimated prevalence of nosocomial pneumonia in intensive care units ranges from $10-65 \%$ with mortality rates of 13 to $55 \%$ (Kollef and Schuster, 1994; Pawar et al., 2003).

The etiologic agents widely differ according to the population of patients in an intensive care unit, duration of hospital stay, and prior antimicrobial therapy (Chastre and Fagon, 2002). Multidrug resistant pathogens such as Pseudomonas spp, Acinetobacter spp and 
Staphylococcus aureus were the common organism causing Ventilator Associated Pneumonia.

Antimicrobial resistance is an increasing threat in hospitalized patients, and inappropriate empirical antimicrobial therapy is known to adversely affect outcomes in ventilator-associated pneumonia (Hsueh et al., 2005; Rhomberg et al., 2004). Therefore, it is necessary to evaluate antimicrobial usage, incidence, etiology and antimicrobial resistance trends for prominent nosocomial pathogens causing ventilator associated pneumonia in an intensive care unit (ICU).

Hence, the aim of this study was to determine the microbial profile of pathogens causing VAP and their antibiotic susceptibility patterns over a period of five years in the intensive care unit (ICU) of a tertiary care hospital.

\section{Materials and Methods}

Cross-sectional, descriptive study was done on patients who were on mechanical ventilation for more than 48 hours and clinically suspected of having pneumonia for the five consecutive years 2012 to 2016. The total number of patients included in this study were 581.

For diagnosis of VAP, a colony count of $\geq 10^{5}$ colony forming units (cfu) / $\mathrm{ml}$ was considered significant (Ioanas et al., 2001). Any growth below this was assumed as colonization or contamination. Quantitative culture of the endotracheal aspirates was performed and organism isolated was identified based on standard microbiological techniques.

Antimicrobial susceptibility testing was performed on Mueller Hinton agar using Kirby- Bauer disk diffusion method (CLSI,
2012) and Zone diameter was measured and interpreted as per the Clinical and Laboratory Standards Institute (CLSI) guidelines.

Ampicillin, Ciprofloxacin, Cefotaxime, Gentamicin, Amikacin, and Imipenem were tested for Enterobacteriaceae. Amikacin, Gentamicin, Ceftazidime, Ciprofloxacin and Imipenem were tested for Pseudomonas spp. and Acinetobacter spp. Penicillin, Erythromycin, Cefotaxime, Ciprofloxacin, Amikacin and Vancomycin (MIC) were tested for S. aureus.

Isolates showing zone diameter of $\leq 22 \mathrm{~mm}$ for Cefotaxime and $\leq 17 \mathrm{~mm}$ for Ceftazidime were considered as screening test for ESBL producers according to CLSI guidelines and were confirmed by double disk synergy test. Combination disk method using both Cefotaxime and Ceftazidime alone and in combination with clavulanic acid was performed for detection of Extended Spectrum Beta Lactamase (ESBL) among the members of Enterobacteriaceae. Five $\mathrm{mm}$ or more increase in zone of inhibition for either Cefotaxime-clavulanic acid or Ceftazidimeclavulanic acid disk compared to the Cefotaxime or Ceftazidime disk respectively was taken as confirmatory evidence of ESBL production.

Cefoxitin $(30 \mu \mathrm{g})$ disc was used as a surrogate marker for determining methicillin resistance among the staphylococci. ATCC strains of Escherichia coli ATCC 25922, Staphylococcus aureus (MSSA) ATCC 25923, MRSA ATCC 33591 and Pseudomonas aeruginosa ATCC 27853 strains were used as quality control.

\section{Results and Discussion}

A total number of 581 patients were included in our study. During the study period significant growth of pathogens were found in 
216 / 581patients.44/112 (39.28\%) in 2012, $43 / 114(37.71 \%)$ in $2013,42 / 106(39.62 \%)$ in 2014, 44/127 (34.64\%) in 2015 and 43/122 $(35.24 \%)$ in 2016.

Two hundred and thirty seven isolates were identified from 216 VAP patients. 90.27\% were monomicrobial $9.72 \%$ were polymicrobial. Among 237 bacteria, 206 $(86.91 \%)$ were gram-negative bacteria. In all the five years Pseudomonas aeruginosa was the most commonly isolated gram-negative bacteria $69 / 206$ (33.49\%) isolates followed by Klebsiella species 59 (28.64\%), Acinetobacter species $26 \quad(12.62 \%)$, Escherichia coli 21 (10.19\%) Proteus species 16 (7.76\%), and Citrobacter species $15(7.28 \%)$.

An increase in resistance was shown by Pseudomonas aeruginosa for Gentamycin, Ciprofloxacin and Ceftazidime ranging from $40 \%$ in 2012 to $72.72 \%$ in 2016. Amikacin ranges from $26.66 \%$ in 2012 to $38.46 \%$ in 2015, in 2016 it was $36.36 \%$. For Imipenem $13.13 \%$ in 2012 to $27.27 \%$.in 2016.

For Acinetobacter spp resistance remains high for most of the antimicrobials ranging from 50 $\%$ to $100 \%$ except for Imipenem (16.66 \% to $40 \%)$.

2012 to 2016 almost all Enterobacteriaceae isolates were resistant to Ampicillin and Gentamycin $(50 \%-100 \%)$.

Klebsiella spp was totally resistant to Ampicillin (100 \%) and showed increased resistance to Gentamycin, Ciprofloxacin and Cefotaxime $(50.00 \%$ - $77.73 \%)$.

Escherichia coli and Proteus spp showed high resistant to Gentamycin, Cefotaxime and Ampicillin (50 \% to 100\%). All the Citrobacter spp were almost resistant to Amikacin, Gentamycin, Ciprofloxacin, Cefotaxime and Ampicillin (50 to 100\%).
$58.49 \%$ of Klebsiella spp and $52.00 \%$ of Escherichia coli were ESBL producers.

Staphylococcus aureus was the most commonly isolated gram positive bacteria (24), 18 (75\%) were Methicillin resistant (MRSA). Forty percent of the CONS (Coagulase-negative Staphylococcus aureus) were resistant to Cefotaxime, Ciprofloxacin and Erythromycin and all the isolates were resistant to Penicillin. However, all the gram positive cocci were sensitive to Vancomycin.

Fungal isolates were 16, Candida species 12 and Aspergillus species 4.

Ventilator associated pneumonia (VAP) is a major problem and it is one of the most frequently encountered hospital acquired infection in the ICU.

The microbial profile of pathogens causing VAP may differ between hospitals and ICUs. Therefore, surveillance of bacterial susceptibility should be conducted and local epidemiological data should be provided for every ICU.

This information can help in guiding the initial empiric antibiotic therapy, which would be useful in decreasing mortality and preventing development of MDR bacteria (Iregui et al., 2002; Leroy et al., 2003; Clec'h et al., 2004).

In our study initial 3 years the VAP rate was high $(39.28 \%, 37.71 \%$ \& 39.62\%) compared to the last 2 years $(34.64 \% \& 35.24 \%)$.

Gram negative bacilli were the most common agents responsible for VAP and it is accounted for $86.91 \%$ of the causative agents. Similar results were shown by (Fugon et al., 1989) who reported an incidence of $75 \%$ of gram negative bacilli and (Smsek et al., 2001) who reported an incidence of $72 \%$ of gram negative bacilli. 
Distribution of pathogen (2012- 2016)

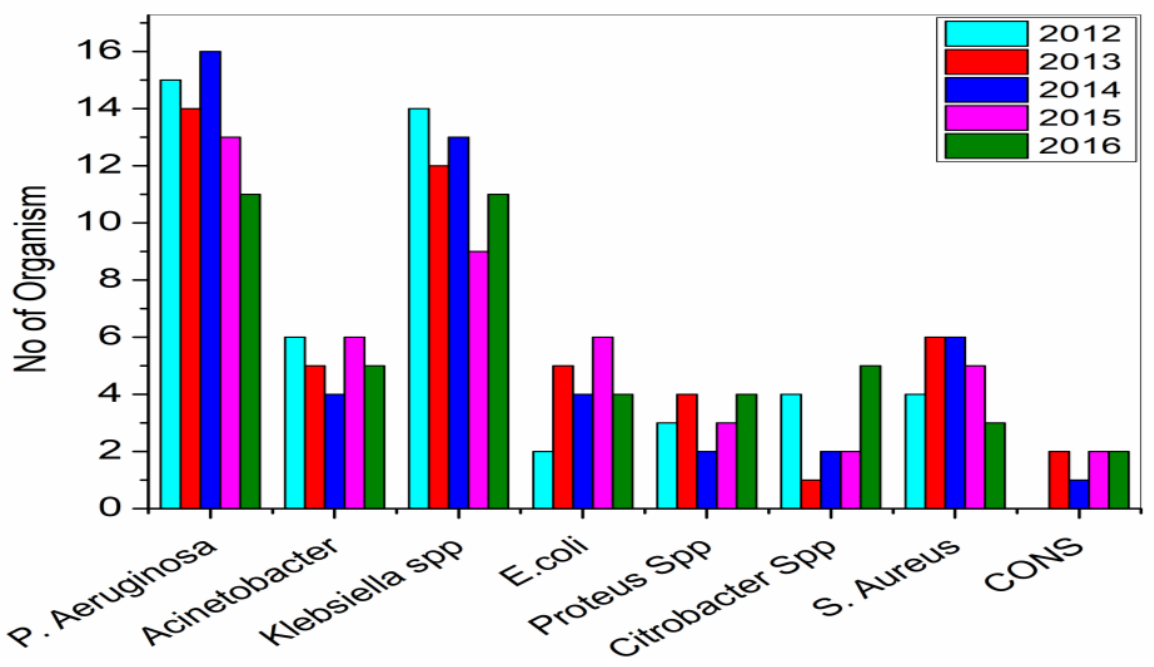

Distribution of VAP pathogen (2012- 2016)

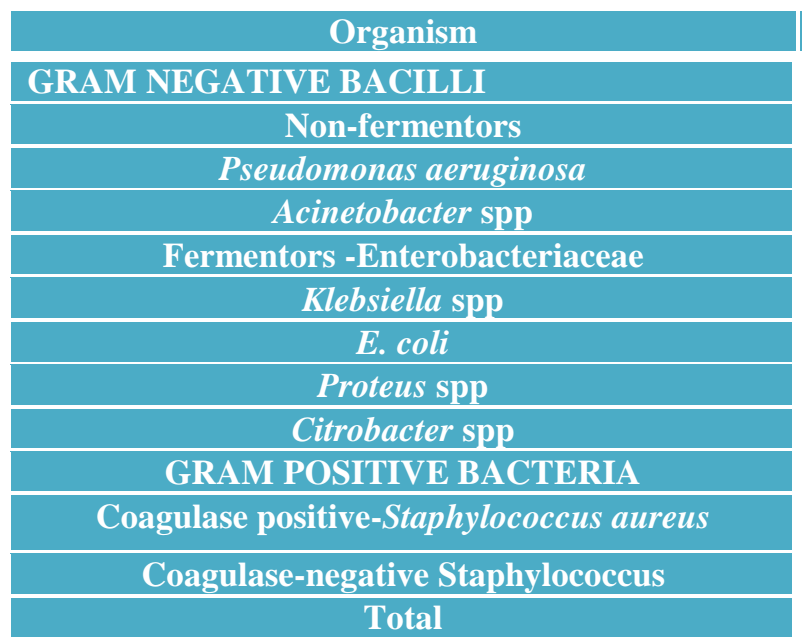

\begin{tabular}{|c|c|c|c|c|}
\hline 2012 & 2013 & 2014 & 2015 & 2016 \\
\hline 15 & 14 & 16 & 13 & 11 \\
\hline 6 & 5 & 4 & 6 & 5 \\
\hline 14 & 12 & 13 & 9 & 11 \\
\hline 2 & 5 & 4 & 6 & 4 \\
\hline 3 & 4 & 2 & 3 & 4 \\
\hline 4 & 1 & 2 & 3 & 5 \\
\hline 4 & 6 & 6 & 5 & 3 \\
\hline 0 & 2 & 1 & 2 & 2 \\
\hline 48 & 49 & 48 & 47 & 45 \\
\hline
\end{tabular}

Antimicrobial Resistance of Non Fermenters

\begin{tabular}{|c|c|c|c|c|c|c|}
\hline $\begin{array}{l}\text { Antimicrobial } \\
\text { agents }\end{array}$ & Year & $\begin{array}{l}\text { AMIKACIN } \\
30 \mu \mathrm{g}\end{array}$ & $\begin{array}{c}\text { GENTAMYCIN } \\
10 \mu \mathrm{g}\end{array}$ & $\begin{array}{c}\text { CIPROFLOXACIN } \\
5 \mu \mathrm{g}\end{array}$ & $\begin{array}{l}\text { CEFTAZIDIME } \\
30 \mu \mathrm{g}\end{array}$ & $\begin{array}{l}\text { IMIPENEM } \\
10 \mu \mathrm{g}\end{array}$ \\
\hline \multirow{5}{*}{$\begin{array}{l}\text { Pseudomonas } \\
\text { aeruginosa }\end{array}$} & 2012 & 26.66 & $\mathbf{5 3 . 5 3}$ & 40.00 & 53.53 & 13.13 \\
\hline & 2013 & 35.71 & 64.20 & 42.85 & 57.14 & 21.42 \\
\hline & 2014 & 37.50 & 62.50 & 43.75 & 56.65 & 25.00 \\
\hline & 2015 & 38.46 & 69.23 & 38.46 & 61.53 & 23.07 \\
\hline & 2016 & 36.36 & 72.72 & 54.54 & 63.63 & 27.27 \\
\hline \multirow{5}{*}{$\begin{array}{l}\text { Acinetobacter } \\
\text { spp }\end{array}$} & 2012 & 66.66 & 83.30 & 50.00 & 50.00 & 16.66 \\
\hline & 2013 & 60.00 & 80.00 & 80.00 & 60.00 & 20.00 \\
\hline & 2014 & 75.00 & 100 & 75.00 & 75.00 & 40.00 \\
\hline & 2015 & 66.60 & 83.33 & 83.33 & 66.66 & 33.00 \\
\hline & 2016 & 80.00 & 100 & 80.00 & 80.00 & 40.00 \\
\hline
\end{tabular}




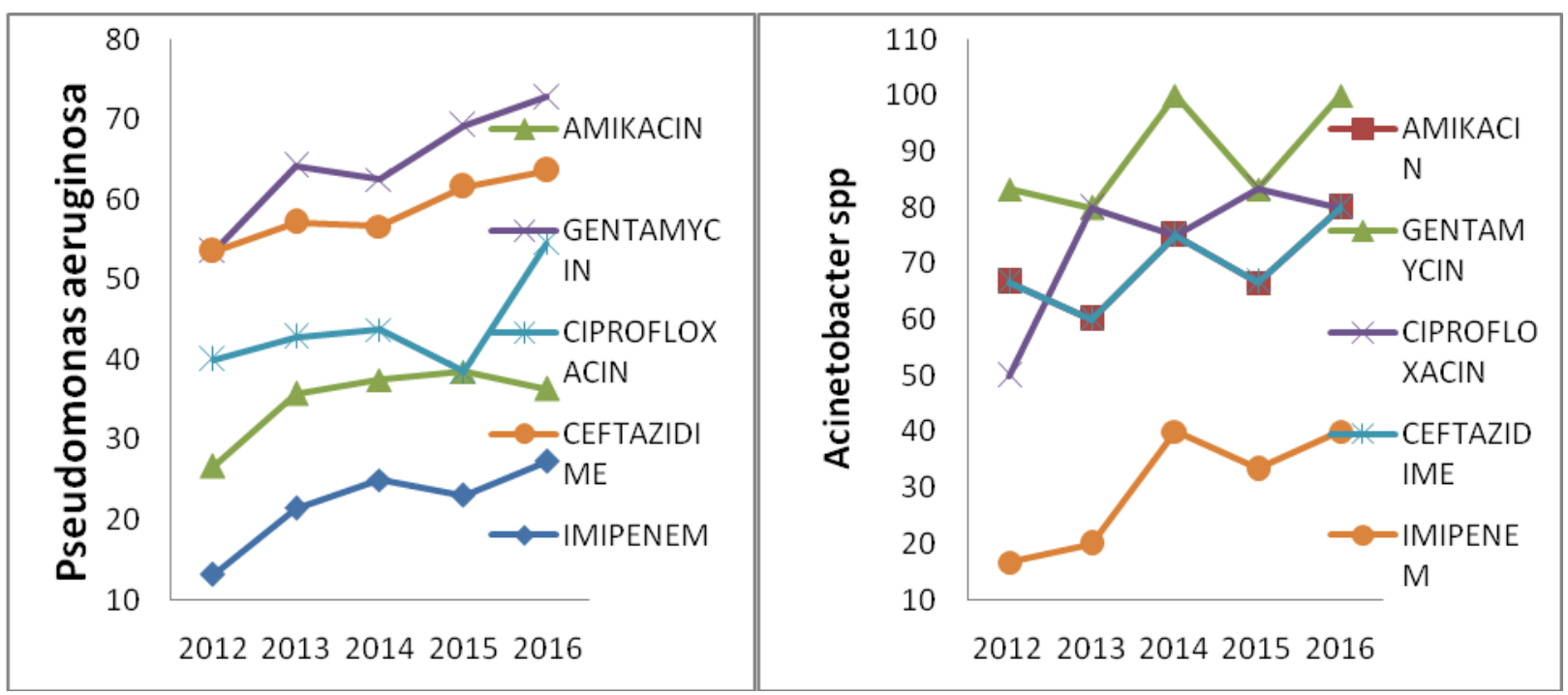

Antimicrobial resistance of enterobacteriaceae

\begin{tabular}{|c|c|c|c|c|c|c|c|}
\hline $\begin{array}{l}\text { Antimicrobial } \\
\text { agents }\end{array}$ & Year & $\begin{array}{l}\text { Amika } \\
\text { cin } \\
30 \mu g\end{array}$ & $\begin{array}{c}\text { Gentamyc } \\
\text { in } \\
10 \mu g\end{array}$ & $\begin{array}{c}\text { Ciprofloxac } \\
\text { in } \\
5 \mu g\end{array}$ & $\begin{array}{l}\text { Cefotaxim } \\
30 \mu \mathrm{g}\end{array}$ & $\begin{array}{c}\text { Ampicillin } \\
10 \mu \mathrm{g}\end{array}$ & $\begin{array}{c}\text { Imipenem } \\
10 \mu \mathrm{g}\end{array}$ \\
\hline \multirow{5}{*}{ Klebsiella spp } & 2012 & 35.71 & $64.2^{\prime}$ & 57.14 & 50.00 & 100 & 7.1 \\
\hline & 2013 & 41.66 & 66.66 & 58.00 & 58.33 & 100 & 8.3 \\
\hline & 2014 & 38.46 & 69.23 & 61.53 & 53.84 & 100 & 15.38 \\
\hline & 2015 & 44.44 & 66.66 & 77.73 & 66.66 & 100 & 22.22 \\
\hline & 2016 & 45.44 & 72.72 & 72.72 & 63.63 & 100 & 27.27 \\
\hline \multirow{5}{*}{$\begin{array}{l}\text { Escherichia } \\
\text { coli }\end{array}$} & 2012 & 50.00 & 50.00 & 50.00 & 50.00 & 100 & 0 \\
\hline & 2013 & 40.00 & 60.00 & 40.00 & 60.00 & 80.00 & 20.00 \\
\hline & 2014 & 50.00 & 50.00 & 50.00 & 50.00 & 75.00 & 0 \\
\hline & 2015 & 33.33 & 66.66 & 50.00 & 50.00 & 66.66 & 16.66 \\
\hline & 2016 & 50.00 & 75.00 & 50.00 & 50.00 & 100 & 25.00 \\
\hline \multirow{5}{*}{ Proteus spp } & 2012 & 33.33 & 66.66 & 33.33 & 66.66 & 66.66 & 0 \\
\hline & 2013 & 50.00 & 50.00 & 50.00 & 75.00 & 50.00 & 25.00 \\
\hline & 2014 & 50.00 & 100.00 & 50.00 & 50.00 & 50.00 & 0 \\
\hline & 2015 & 66.66 & 66.66 & 66.66 & 66.66 & 66.66 & 33.33 \\
\hline & 2016 & 75.00 & 100.00 & 75.00 & 50.00 & 50.00 & 25.00 \\
\hline \multirow{5}{*}{$\begin{array}{l}\text { Citrobacter } \\
\text { spp }\end{array}$} & 2012 & 50.00 & 75.00 & 50.00 & 50.00 & 50.00 & 25.00 \\
\hline & 2013 & 100 & 100.00 & 100 & 100 & 100 & 0 \\
\hline & 2014 & 50.00 & 50.00 & 50.00 & 50.00 & 50.00 & 50.00 \\
\hline & 2015 & 66.66 & 66.66 & 66.66 & 66.66 & 66.66 & 33.33 \\
\hline & 2016 & 60.00 & 80.00 & 60.00 & 60.00 & 80.00 & 40.00 \\
\hline
\end{tabular}


Int.J.Curr.Microbiol.App.Sci (2018) 7(5): 288-297
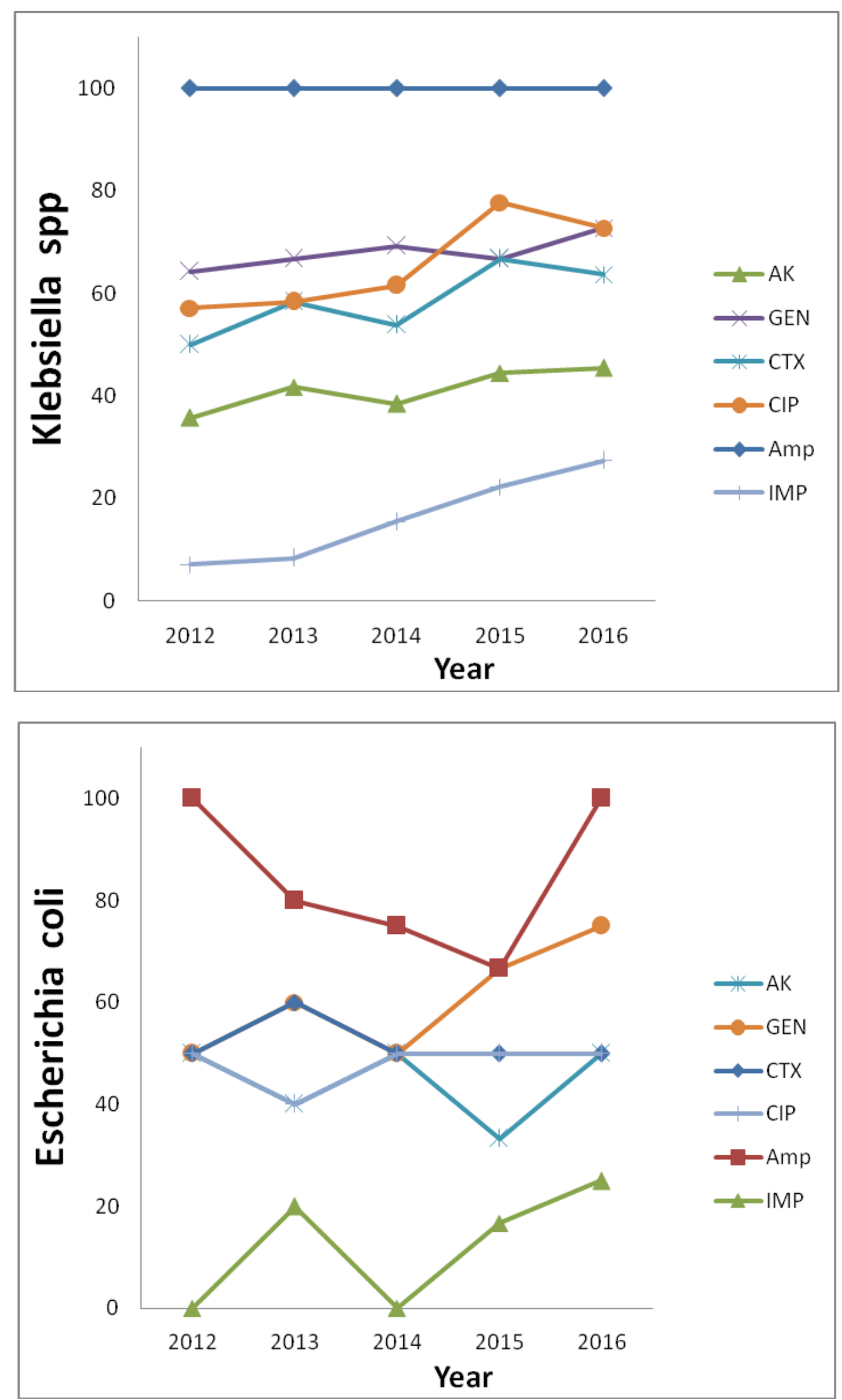
Int.J.Curr.Microbiol.App.Sci (2018) 7(5): 288-297
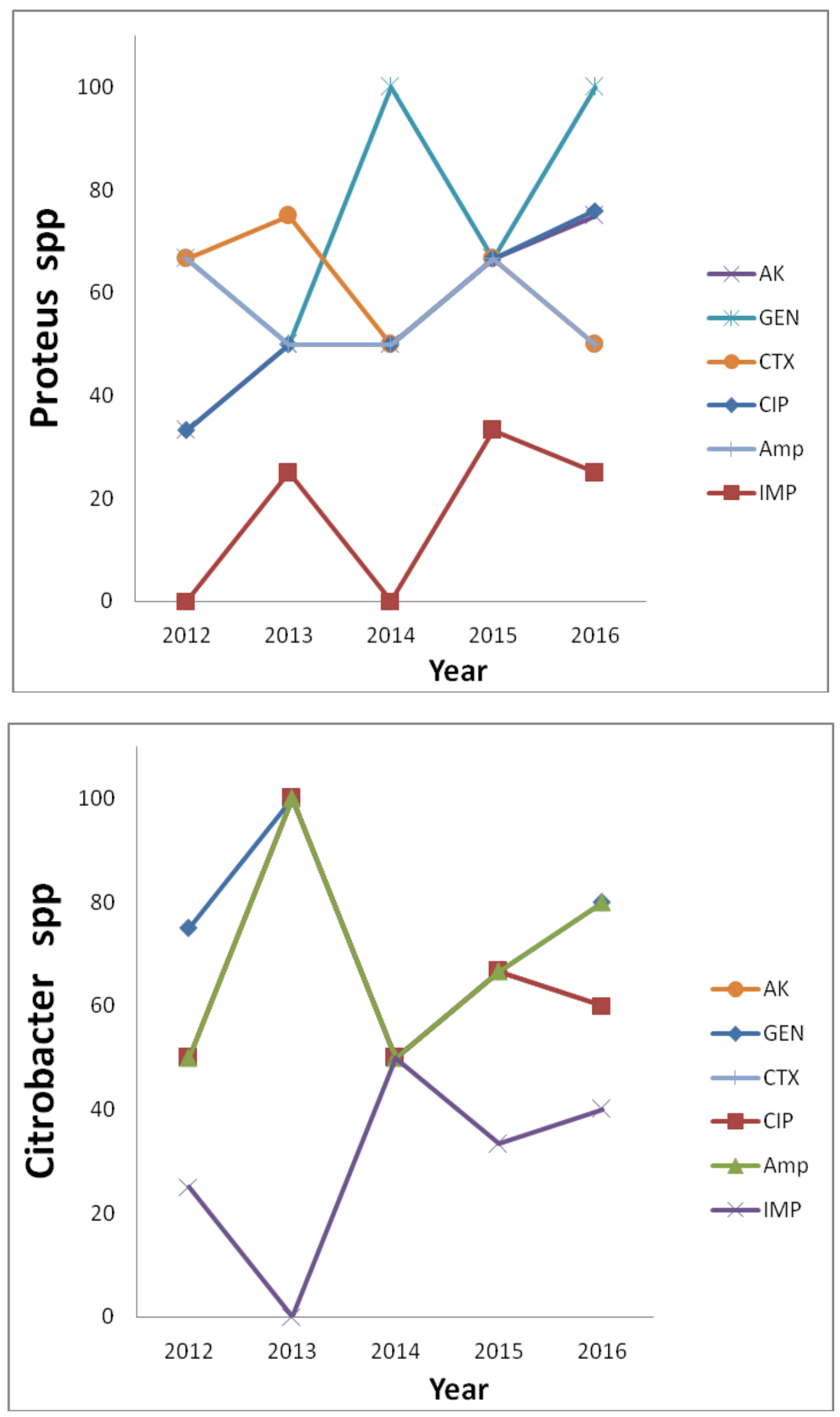
Antimicrobial resistance of gram positive cocci

\begin{tabular}{|c|c|c|c|c|c|c|c|}
\hline $\begin{array}{c}\text { Antimicro } \\
\text { bial } \\
\text { agents }\end{array}$ & Year & $\begin{array}{c}\text { Penicillin } \\
10 u\end{array}$ & $\begin{array}{c}\text { Erythro } \\
\text { mycin } \\
15 \mu g\end{array}$ & $\begin{array}{l}\text { Cefotaxime } \\
30 \mu g\end{array}$ & $\begin{array}{c}\text { Cipro } \\
\text { floxacin } \\
5 \mu \mathrm{g}\end{array}$ & $\begin{array}{c}\text { Amikacin } \\
30 \mu g\end{array}$ & $\begin{array}{c}\text { Vanco } \\
\text { mycin } \\
\text { MIC }\end{array}$ \\
\hline \multirow{5}{*}{$\begin{array}{l}\text { Staphylo } \\
\text { coccus } \\
\text { aureus }\end{array}$} & 2012 & 75.00 & 25.00 & 25.00 & 25.00 & 25.00 & 0 \\
\hline & 2013 & 100 & 33.33 & 33.33 & 33.33 & 33.33 & $\mathbf{0}$ \\
\hline & 2014 & 100 & 50.00 & 50.00 & 33.33 & 33.33 & 0 \\
\hline & 2015 & 100 & 40.00 & 40.00 & 60.00 & 60.00 & 0 \\
\hline & 2016 & 100 & 66.66 & 66.66 & 66.66 & 66.66 & 0 \\
\hline \multirow{5}{*}{$\begin{array}{l}\text { Coagulase } \\
\text { negative } \\
\text { Staphylo } \\
\text { coccus }\end{array}$} & 2012 & - & - & - & - & - & - \\
\hline & 2013 & 100 & 50.00 & 100 & 50.00 & 50.00 & 0 \\
\hline & 2014 & 100 & 100 & $\mathbf{0}$ & 100.00 & 0 & 0 \\
\hline & 2015 & 100 & 50.00 & 100 & 100.00 & 50.00 & 0 \\
\hline & 2016 & 100 & 100 & 100 & 50.00 & 50.00 & 0 \\
\hline
\end{tabular}

It was found that $9.72 \%$ of bacterial cultures were polymicrobial, while variable results have been reported in other studies ranging from $13 \%$ to $80 \%$.

Among the gram negative organism, in all the five years, Pseudomonas aeruginosa was the predominant isolates, accounting for 69 of 206 (33.49 \%) isolates. The next most commonly isolated bacteria were Klebsiella species $(28.64 \%)$ followed by Acinetobacter species (12.62), Escherichia coli (10.19) Proteus species (7.76), and Citrobacter species (7.28). The study conducted by (Rajesh Chawla, 2008) showed 31\% of Pseudomonas aeruginosa and $20 \%$ of Klebsiella sp among gram negative bacilli.

Most of the organism remained more or less same over the five years, a small decrease in the incidence of Pseudomonas aeruginosa and Staphylococcus aureus was seen.

Currently, antimicrobial resistance rates are increasing among Pseudomonas aeruginosa and Acinetobacter species.

An increase in resistance was shown by Pseudomonas aeruginosa (ranging from
42.85 percent to 72.72 percent) for Gentamycin, ciproflaxacin and Ceftazidime. For Amikacin 26.66 percent to 38.46 percent and for Imipenem 13.13 percent to 25.00 percent. For Acinetobacter spp resistance remains very high for most of the antimicrobials ranging from 50 percent to 100 percent except for Imipenem (16.66\% to 40 $\%)$.

Among the Enterobacteriacea $58.49 \%$ of Klebsiella spp and $52.00 \%$ of Escherichia coli were found to be ESBL producers. The emergence of extended spectrum betalactamase (ESBLs) necessitated the increase use of carbapenems, but this increased use of drugs may be contributing to the emergence of multidrug resistant Gram negative bacilli. All the ESBL producing isolates were sensitive to Imipenem in this study.

VAP due to Gram positive bacteria (13.08\%) were relatively less. MRSA is another global problem, this study showed among all Staphylococcus aureus isolates, 18 (75.00\%) isolates were methicillin resistant $S$. aureus (MRSA). It correlates with the study of Naouel Mandani $78.3 \%$ were resistant to 
Methicillin. More than forty percent of the CONS (Coagulase negative Staphylococcus aureus) were resistant to cefotaxime, ciprofloxacin and erythromycin and all the isolates were resistant to Penicillin.

However all the gram positive cocci were sensitive to vancomycin. Hence Vancomycin should be part of regimen because Staphylococcus aureus is the most frequent gram positive isolates with high methicillin resistance rates

Despite the advancements in antimicrobial regimes, VAP continues to be an important cause of morbidity and mortality. Hence, knowing the local microbial flora causing VAP, their antibiotic resistant pattern and effective infection control practices are essential to improve clinical outcomes.

From this study we can conclude that VAP is an important nosocomial infection Pseudomonas aeruginosa was the commonest organism isolated.

Increasing drug resistance rates among gramnegative pathogens that frequently cause ventilator-associated pneumonia have resulted in increased hospital mortality, longer hospital stays, and higher inpatient health care costs.

Hence Good management strategies for VAP like adequate infection control practices include hand washing by hospital personel, basic cleaning of all surface levels, increased barrier precautions, early accurate diagnosis and more specific antimicrobial use may significantly improve patients' outcome.

A multidisciplinary approach, coordinated participation of microbiologist, clinician, nursing personel and hospital infection control team is necessary for management of this nosocomial infection.

\section{References}

American Thoracic Society and Infectious Diseases Society of America. (2005). Guidelines for the management of adults with hospital-acquired, ventilator-associated, and healthcareassociated pneumonia. Am J Respir Crit Care Med, 171, 388-416.

Chastre, J and Fagon, J. Y. (2002). Ventilatorassociated pneumonia. American journal of respiratory and critical care medicine, 165(7), 867-903.

Chawla, R. (2008). Epidemiology, etiology, and diagnosis of hospital-acquired pneumonia and ventilator-associated pneumonia in Asian countries. American journal of infection control, 36(4), S93-S100.

Clec'h, C., Timsit, J. F., De Lassence, A., Azoulay, E., Alberti, C., GarrousteOrgeas, M and Cohen, Y. (2004). Efficacy of adequate early antibiotic therapy in ventilator-associated pneumonia: influence of disease severity. Intensive care medicine, 30(7), 1327-1333.

CLSI - Clinical and Laboratory Standards Institute 2012. Performance standards for antimicrobial susceptibility testing. Twenty-second informational supplement. Wayne, PA, USA: CLSI: 2012; M100-S22.

Fagon, J. Y., Chastre, J., Domart, Y., Trouillet, J. L., Pierre, J., Darne, C and Gibert, C. (1989). Nosocomial pneumonia in patients receiving continuous mechanical ventilation: prospective analysis of 52 episodes with use of a protected specimen brush and quantitative culture techniques. American Review of Respiratory Disease, 139(4), 877-884.

Hsueh, P. R., Chen, W. H and Luh, K. T. (2005). Relationships between antimicrobial use and antimicrobial 
resistance in Gram-negative bacteria causing nosocomial infections from 1991-2003 at a university hospital in Taiwan. International journal of antimicrobial agents, 26(6), 463-472.

Ioanas, M., Ferrer, R., Angrill, J., Ferrer, M and Torres, A. (2001). Microbial investigation in ventilator-associated pneumonia. European Respiratory Journal, 17(4), 791-801.

Iregui, M., Ward, S., Sherman, G., Fraser, V. J and Kollef, M. H. (2002). Clinical importance of delays in the initiation of appropriate antibiotic treatment for ventilator-associated pneumonia. Chest, 122(1), 262-268.

Kalanuria, A. A., Zai, W and Mirski, M. (2014). Ventilator-associated pneumonia in the ICU. Critical care, 18(2), 208.

Kollef, M. H and Schuster, D. P. (1994). Ventilator-associated pneumonia: clinical considerations. AJR. American journal of roentgenology, 163(5), 10311035.

Leroy, O., Meybeck, A., d'Escrivan, T., Devos, P., Kipnis, E and Georges, H.
(2003). Impact of adequacy of initial antimicrobial therapy on the prognosis of patients with ventilator-associated pneumonia. Intensive care medicine, 29(12), 2170-2173.

Pawar, M., Mehta, Y., Khurana, P., Chaudhary, A., Kulkarni, V and Trehan, N. (2003). Ventilator-associated pneumonia: incidence, risk factors, outcome, and microbiology. Journal of cardiothoracic and vascular anesthesia, 17(1), 22-28.

Rhomberg, P. R., Jones, R. N and Sader, H. S. (2004). Results from the Meropenem Yearly Susceptibility Test Information Collection (MYSTIC) Programme: report of the 2001 data from 15 United States medical centres. International journal of antimicrobial agents, 23(1), 52-59.

Simsek, S., Yurtseven, N., Gercekogalu, H., Izgi, F., Sohtorik, U., Canik, S and Ozler, A. (2001). Ventilator-associated pneumonias in a cardiothoracic surgery centre postoperative intensive care unit. Journal of Hospital Infection, 47(4), 321-324.

\section{How to cite this article:}

Shanthi, B., R. Selvi, V. Sheeba and Ponnammal, P. 2018. Microbial Profile and their Susceptibility Pattern in Ventilator Associated Pneumonia in a Tertiary Care Hospital. Int.J.Curr.Microbiol.App.Sci. 7(05): 288-297. doi: https://doi.org/10.20546/ijcmas.2018.705.037 